\title{
Accommodations Taxes in the Local Finance Structure: A South Carolina-Based Evaluation
}

\author{
Holley H. Ulbrich*
}

In a search for solutions to a growing revenue-expenditure imbalance in some counties and municipalities, the South Carolina General Assembly has been considering several options. One possibility is a local option accommodations tax. Although such a tax is in effect in twenty-four states and the District of Columbia, there exists virtually no literature on the subject of specific excise taxes, to which class the proposed tax belongs. This paper attempts to fill this gap with an analysis of the accommodations tax in a South Carolina context.

The first section will examine the background of the revenue-expenditure imbalance. The second section develops criteria for comparing this tax or any proposed local tax, to the property tax. Section III evaluates the accommodations tax in comparison to the property tax on the basis of these criteria. Section IV is a summary and conclusions.

\section{BACKGROUND}

One of the most pressing fiscal issues of the 1970s has been the disparity between the fiscal capacity of local governments and the increasing expenditure demands placed on them by both the local constituency and higher levels of government. Local communities have three options when expenditures grow more rapidly than revenues. They can attempt to raise more revenues from existing sources, they can try to control expenditures, or they can implement new revenue sources.

The first avenue was pursued by local governments in South Carolina and elsewhere in the 1970s in the form of higher local property tax rates. Higher rates were necessary because the property tax base is relatively insensitive to overall economic growth and/or inflation. ' While expenditures are highly sensitive to both, the forecasted annual growth rate of the property tax base in South Carolina 1976-1990 is only 1.5 percent for counties and 1.6 percent for municipalities. ${ }^{2}$ The second most significant local revenue source has been intergovernmental grants. These are, unfortunately, outside the control of 
local governments, and have been both slow to increase and highly uncertain in the 1970s. South Carolina froze state-shared revenues in 1974 and has yet to fully restore the allocations at this writing.

The second path is to attempt to control the growth of expenditures. Unfortunately, most of the sources of increased local expenditure demands are beyond the control of local government. Inflation has been a significant culprit; much of local government's expenditures are for labor intensive services, with little scope for productivity increases. From 1960 to 1976 the implicit price deflator for state and local government rose $144 \%$ while the overall GNP deflator rose only $95 \%$. Affluence is a second source of the expenditure crunch; both cross-sectional and time series studies indicate that the public sector grows more rapidly than GNP as GNP rises. ${ }^{3}$ Mandates from higher levels of government (e.g. water quality, affirmative action, police training) come without the financing required to implement them. Grants from higher levels of government may require matching local spending and/or creating facilities and programs which the local government must continue to finance later. Finally, population growth, increased density, or (paradoxically) increased dispersion can impose additional expenditure demands on local governments. Localities may have some limited options in controlling expenditures, but most of the determinants of rising expenditures appear to be beyond their control.

This leaves new revenue sources as the most promising direction by default. However, there is at least one advantage in turning to new revenue sources, particularly in the case of the new tax under discussion in this paper. Any new tax will broaden the array of revenue instruments at the disposal of local governments, and this diversification can "improve" the tax structure in several respects, among them the following:

1. Any single tax can be at least partly avoided by the judicious arrangement of one's financial affairs. The property tax, for example, can be lessened in proportion to one's income by putting a higher percentage of assets into forms not subject to the property tax. With a more diversified base this kind of tax avoidance becomes more difficult.

2. No tax rates a perfect score on any array of criteria-equity, yield, cyclical stability, neutrality, income elasticity, certainty, and other desirable qualities. The more diversified the tax base, the better is the balance among conflicting attributes it is possible to attain.

3. A diversity of local revenue sources may reduce local dependence on inter-governmental grants which have proved to be somewhat capricious in nature.

The search for supplementary local tax revenue sources quickly narrows down to some already in widespread use-in particular, local sales, income and specific excise taxes. It must be borne in mind that in a federal system it is 
local government which is most vulnerable to locational non-neutrality in a potential tax source. It is far easier to relocate in another county or municipality or outside the municipal jurisdiction than it is to escape new or higher state or federal taxes by relocation. "Voting with one's feet" against higher taxes or new taxes does not preclude local sales taxes, income taxes, or property taxes, but it does put some upper limits on rates and revenue capacity relative to adjacent jurisdictions. This problem is particularly acute in urban areas which provide some municipal functions for a broader area from which the municipality is unable to extract tax revenues. New York City's unpopular "commuter tax" was one example of an effort to deal with the fiscal problems created by the quasi-public-good nature of a large city.

\section{CRITERIA FOR EVALUATION}

Because of these difficulties the criteria for evaluating a potential addition to the local tax structure cannot be limited to the most obvious single question of revenue yield. If this were the sole criterion, the proposed hotel-motel accommodations tax would be rejected out of hand, except for a limited number of tourist centers where it has substantial revenue potential. Excise taxes, tariffs, effluent charges, many user fees, inheritance taxes and other specialized taxes whose purposes are multi-faceted in terms of incentives, equity, and other supplementary criteria, would be equally vulnerable to rejection on the basis of a simple revenue test.

The criteria assembled during the course of this project reflects those which dominate the public finance literature. ${ }^{4}$ They are as follows:

1. Adequacy - Percent of 1975 total revenues actually (property) or potentially ( $2 \%$ accommodations tax) raised from this source.

2. Neutrality - A nonquantifiable criterion, referring to the extent to which this tax is expected to distort economic decisions in comparison to other taxes.

3. Administrative Cost - Administrative expenditures as a percentage of revenue collected.

4. Growth Potential - Income elasticity, using both real income and nominal income. The latter captures inflation sensitivity.

5. Cyclical Stability - Absolute percentage change from the trough to peak of a business cycle, using the 1974 cycle. (Dates: peak 4th quarter 1973, trough 1st quarter 1975, peak 2nd quarter 1976).

6. Equity - Again, a somewhat subjective criterion. A tax generally receives a higher equity rating than another if it is more progressive i.e., $\frac{\% \Delta \text { tax yield }}{\% \Delta \text { income }}>1$ on a cross sectional basis.

7. Nonresident Contribution - Also difficult to quantify. Refers to the share of the tax borne by nonresidents. Ideally, this would bear some appropriate relationship to the use of local government services by nonresidents. 
8. Distribution of Revenue - Relationship between revenue potential and perceived fiscal distress.

No single tax will receive a perfect score on all of these eight criteria, which is itself an argument for a multi-source local revenue system. Table 1 summarizes the comparative rankings for the property tax and the accommodations tax on these criteria as defined below.

TABLE 1

Rating for

\begin{tabular}{lll}
\hline Criterion & Property Tax & Accommodations Tax \\
\hline Adequacy & Good & Fair to poor \\
Neutrality & Fair & Fair to good \\
Adequacy & Good & Fair to poor \\
Neutrality & Fair & Fair to good \\
Administrative Cost & Fair & Excellent \\
Growth Potential & Poor to Fair & Good to Excellent \\
Cyclical Stability & Good to Excellent & Fair \\
Equity & Poor to Fair & Good to Excellent \\
Nonresident Contribution & Poor to Fair & Good to Excellent \\
Distribution of Revenue & Fair & Fair to good \\
\hline
\end{tabular}

Section III provides a more detailed discussion of these relative rankings.

\section{RELATIVE EVALUATION}

\section{Adequacy}

The property tax generally has far greater revenue potential than an accommodations tax since the latter has a relatively narrow base. Revenue estimates were computed only for the 28 (out of 46) counties and 37 (out of 246) municipalities which had more than 100 rooms available. The estimated revenue $^{5}$ ranged from $\$ 11,114$ (Newberry) to more than $\$ 4$ million (Myrtle Beach). There were only eight municipalities and eleven counties where this tax raised revenue equal to more than 3 percent of current property tax revenues. Only three municipalities (Cayce, Florence and Myrtle Beach) and six counties, most of them on the coast, would generate more than 10 percent of current property tax revenues from such a tax. Only Myrtle Beach and Horry County in which it is located could more than replace total property tax collections with the accommodations tax. Clearly, on adequacy grounds, the accommodations tax must be viewed as a complement to rather than a significant substitute for the property tax. 


\section{Neutrality}

Neutrality can be interpreted in terms of reallocating consumption away from accommodations toward other purchases in response to the 2 percent tax differential. Estimates of price elasticity of demand for accommodations are difficult to make because a separate lodging index has only been available since 1977. Using occupancy rates as a proxy for quantity and the housing price index as a proxy for relative price, a partial elasticity of -.138 is obtained. However, the t-test for PHOU was only of borderline significance. (The full results are given below in the discussion of growth potential and inflation sensitivity.)

A more serious neutrality question revolves around location effects. If tax is imposed within a municipality but not in the surrounding county, a motel may choose to locate in the county. The location decision will be the result of:

(a) the inconvenience of collecting and remitting the tax

(b) the price differential in nearby adjacent motels inside and outside the city limits, which may have a significant effect on room sales inside city limits, and

(c) the difference in property taxes inside and outside the city; all of which may be at least partially offset by

(d) the benefits to be gained from municipal services.

If (a), (b), and (c) outweigh (d), motels may choose to locate outside city limits, thereby costing the city not only accommodations tax revenue but also property tax revenue. The location of many motels outside city limits in South Carolina is due in most part to the location of major highways, but certainly there are a significant number of motels whose location is designed to minimize property taxes. An additional municipal hotel-motel accommodations tax could be expected to tip the balance even more in favor of out-of-town locations.

County wide taxes would generate similar location questions between adjacent counties with and without accommodations taxes.

The property tax itself has some serious neutrality drawbacks with respect to the form in which wealth is to be held and with respect to tax (and services) differentials between adjacent jurisdictions. Neither tax receives a particularly high score on this criterion.

\section{Administrative Cost}

A "good" tax will not have a large amount of the revenue it generates consumed by the cost of collecting the tax. The more expensive a tax is to administer, the less net revenue it produces. The cost of collection can be reduced either by making the tax easier to pay and to collect or by shifting a large part of the cost of compliance to the taxpayer, as it is true of the income tax. This would also be true to some extent of the sales tax, which is the same kind of tax as the proposed accommodations tax. 
The burden of collection falls partly on the retailer and partly on the Tax Commission. Sales taxes nationally cost about one percent or less of gross revenues to administer.

The incremental or additional cost of administering the proposed accommodations tax, however, would be even less. Hotels and motels are already collecting sales tax, so they would just be collecting the same tax at a higher rate. Except for adjusting the reporting forms, there is no additional cost of collection to the State Tax Commission. Disbursement of revenues to cities and counties would require an initial adjustment of the computer program which determines present disbursement of state-shared revenues to counties and cities. Once this adjustment was made, further incremental costs of disbursement (according to a Tax Commission spokesman) would be extremely low.

While estimates for the administrative cost of the property tax are not available, the highly decentralized administration of an almost purely local tax and the cost of regular assessment and reassessment would appear to put it at a disadvantage on this criterion.

Growth Potential and Cyclical Stability are inversely related. Any revenue source which is highly income sensitive will also be vulnerable to downturns in the level of economic activity. To measure the sensitivity of the accommodations tax revenue base to income changes, the following proxy variables were used. (Total accommodations revenue is not available on a national basis.)

OCCA = occupancy rate, seasonally adjusted

ASR = average sales per room

Explanatory variables were:

RGNP $=$ real gross national product

NGNP = nominal GNP

PHOU $=$ housing price index

An accommodations price index was not available prior to 1977, but the variables entering into housing costs - construction, interest rates, home furnishings, utilities, domestic services, etc. - were a close proxy for the major cost elements of hotel-motel operations.

Data, adjusted from the Survey of Current Business, are quarterly from 1970 to 1977 . The results were as follows:
(1) $\ln$ ASR =
$-5.9735+1.2585 \ln$ NGNP $\quad R^{2}=.931$
(2) $\ln$ ASR $=$
$-21.149+3.6079 \ln \mathrm{RGNP} \quad \mathrm{R}^{2}=.854$
(3) $\ln \mathrm{ASR}=$
$-13.77+1.915 \ln \mathrm{RGNP}+.928$ PHOU
(4) $\ln$ OCCA $=$
$\mathrm{R}^{2}=.938$
(5) $\ln \mathrm{OCCA}=$
$1.880+.3099 \ln \mathrm{NGNP} \quad \mathrm{R}^{2}=.591$
(6) $\ln \mathrm{OCCA}=$
$-3.074+1.073 \ln \mathrm{RGNP} \quad \mathrm{R}^{2}=.778$
$1.455+1.182 \ln$ NGNP -1.1731 PHOU
$\mathrm{R}^{2}=.775$
(7) $\ln \mathrm{OCCA}=$
$-4.173+1.34 \ln$ RGNP -0.138 PHOU
$\mathrm{R}^{2}=.795$ 
TABLE 2

PERCENTAGE CHANGE IN

\begin{tabular}{lccc}
\hline Quarter & RGNP & ASR/PHOU & OCCA \\
\hline $4 / 73$ to $1 / 75$ & $-6.2 \%$ & $-1.2 \%$ & $-9.7 \%$ \\
(Peak to trough) & & & \\
$1 / 75$ to $4 / 76$ & $+8.7 \%$ & $+4.3 \%$ & $+11.1 \%$ \\
(Trough to peak) & & & \\
\hline
\end{tabular}

All $t$ tests are significant at the one percent level except for PHOU in equation (6). Note that in general the signs are as one would expect. Both average sales per room and occupancy are positively related to either real or nominal GNP. Average room sales are understandably positively related to price while the occupancy rate, a far more unequivocal quantity index, has a negative relationship to the price index. The equations indicate that both indirect measure of accommodations "activity" are highly sensitive to fluctuations in GNP and are more sensitive to real GNP (growth and cycles) than to nominal GNP. All of the real GNP coefficients, which are approximate income elasticity measures, are greater than one. Since the addition of the housing price index did not significantly improve $\mathrm{R}^{2}$ for the occupancy rate, and since real GNP consistently performed better than nominal GNP as an explanatory variable for occupancy rate, the effect of the housing price index and thus the price elasticity remains an unanswered question. Perhaps the accommodations price index, when it is available for a sufficient number of time periods, will provide more adequate answers.

An alternate measure of the sensitivity of the tax base to growth and fluctuations is provided indirectly by changes in South Carolina payroll and employment for the lodging industry relative to total payroll and employment in the state. During the period 1970-77 hotel-motel employment grew 41.9 percent versus 21.4 for total private employment; and accommodations payrolls grew 111 percent versus 79 percent for total private payrolls. ${ }^{6}$ To the extent that the industry's payroll and employment accurately reflect accommodations revenues, this clearly appears to be a growth industry. Since a major criticism of the property tax is its low income elasticity (see footnote 1), the accommodations tax would be complementary to the property tax in this report.

While long term growth favors the accommodations tax, this tax lacks the cyclical stability of the property tax. Local governments are under much heavier constraint to keep their budgets approximately in balance than are higher levels of government, and their expenditures drop little (if at all) over the course of a business cycle. Table 2 indicates that while real room sales are not cyclically sensitive, the occupancy rate is highly cyclical. This reflects the discretionary nature of the accommodations purchase. 


\section{Equity}

The accommodations tax falls on two groups, tourists and business travelers. In the case of tourism, travel and recreation are discretionary expenditures which rise and fall more than in proportion to income differentials. In other words, higher income classes spend a larger share of their income on travel and recreation than lower income groups. Thus, the burden of the tax would fall most heavily on higher income groups, especially in the case of a percentage (gross receipts) levy rather than a flat rate. (A flat rate would constitute a higher percentage of room price for a cheaper room and would therefore not be progressive.) Since the state income tax is progressive while sales and property taxes are regressive, gross receipts accommodations tax should help to balance the overall tax structure to some extent by making it less regressive.

To the extent that the tax reduces room sales, it could create some unemployment among the low-wage workers - maids, maintenance workers, waitresses, etc. - who make up most of a hotel or motel staff. This would place some of the burden of the tax on lower income groups. However, the proposed tax is sufficiently small relative to lodging expense in particular and total travel expense in general that no general decline in sales should be expected.

The equity effects of business travel are much more difficult to ascertain since the tax will be reflected in the price of the product or service. There is no a priori reason to assume any relationship between travel expenses per dollar of sales and distribution of final purchases by income classes.

Another important equity question arises in connection with differential assessment, mandated by the South Carolina Constitution. Hotels and motels are assessed at the commercial rate $(6 \%)$ rather than the industrial rate $(9.5 \%)$.

Cities and counties which are major commercial and/or tourist centers provide services to travelers-water, sewer, fire, police, road maintenance, parking airport facilities, convention centers, etc. They also provide such urban amenities as zoos, museums, to encourage travelers of both types. To some extent, these facilities are supported by user charges and to a greater extent by property taxes. But when public facilities - parking, convention centers, zoos, museums, - are constructed, this property is removed from the property tax base. Some offsetting revenue source must be developed. An accommodations tax which has its major impact in cities and tourist areas (see below) may be a partial answer. Since these districts have a heavier concentration of commercial facilities, they have a revenue disadvantage relative to jurisdictions with a higher concentration of industrial property, because of the lower assessment rate on commercial facilities. This also offers justification for a tax which would yield more revenue in areas with a heavy concentration of commercial facilities. However, there are some counter arguments to consider.

Hotel and motel owners understandably object to being singled out for a new tax. However, the differential assessment of commercial and industrial 
property offers a partial justification for assigning a new tax to one of the state's major non-industrial economic sectors. In addition, a major alternative at this point to the accommodations tax is higher property taxes, which would hit transient accommodations fairly heavily. The accommodations tax is easily shifted forward to the room occupants; the increased property tax is more likely to fall at least partially on the property owners.

Innkeepers also point out that tourism generates property tax revenues indirectly. While tourists use public parking, public beaches, airports, museums, they also generate an increase in property-tax paying restaurants, golf courses, and shops which develop to serve their needs. These commercial facilities argue the property tax base. Thus indirectly, through the property taxes on the lodging they rent and on the commercial facilities they use, tourists are already contributing to tax revenue in tourist areas, particularly on the Grand Strand. It could be argued that an accommodations tax is an unfair additional burden.

Tourism is an industry, the main and indeed almost the only industry along much of the coast. While inland cities and counties have industries taxes based on a 10.5 percent assessment rate, the tourist industry is carried out in commercial facilities paying taxes based on a 6 percent assessment. Thus, the tax yield of a service industry is lower relative to the tax yield of a manufacturing industry. Yet both demand services - fire and police protection, road maintenance, water and sewer services, parks and recreation for employees and tourists, and other local services. Thus, the accommodations tax may reduce the imbalance in tax revenue from the local industry base which results from the differential assessment of commercial and industrial property. In addition, this tax generates peak revenue during the tourist season, the period of peak local service demand.

In summary, part of the justification of a tax on commercial and tourist travel lies in the differential assessment of commercial and industrial property and in the service demands imposed on local municipalities (and to a lesser extent counties) by transients.

\section{Nonresident Contribution}

The effort to derive tax revenues from nonresidents is based primarily on their use of public facilities for which they are not taxed and secondarily on redistributional motives. This is true whether we are considering the effort of large municipalities to tax outlying residents (who use the facilities and who are, on the average, in a higher income bracket) or whether the question is the effort of an entire state to tax those who pass through and have tax homes elsewhere. The property tax is relatively more difficult to shift forward and therefore tends to be borne by residents. The accommodations tax however, is borne almost exclusively by nonresidents of the immediate locality. For South Carolina, about two-thirds of the occupants of hotels and motels are nonstate residents as well. Since South Carolina ranks near the bottom of the fifty states 
in per capita income, this tax redistribution may be justified on equity as well as benefit grounds.

\section{Distribution of Yield}

The distribution of potential revenues is related to tourist attractions, major municipal centers, and location along interstate highways. Tourism generates additional pressure on local fire, police, sewage and road maintenance services, which might therefore justify using accommodations as a revenue base in places such as the Grand Strand, Hilton Head, and Santee. Large municipalities were identified as most severely in need of revenues in the Local Finance Study. Therefore, this tax would provide an additional revenue source where it is most urgently needed. Areas located along interstate highways lie in the path of rapid growth where property tax collections tend to lag behind expanded service demands, and might therefore also be in greater than average need of an additional revenue source.

\section{SUMMARY}

The proposed accommodations tax complements the property tax and expands the revenue options of South Carolina cities and counties. Overall revenue yield is not substantial, but there is considerable revenue potential in certain areas, particularly tourist areas. The tax has good growth potential over time, although the yield is somewhat sensitive to cyclical fluctuations in the level of economic activity, both the converse of the property tax. A tax levied in municipalities only may shift some new motel locations outside cities; an optional county tax could shift some motels to adjacent counties. Overall effects of the tax on the base (lodging sales) would probably be modest because the amount of the accommodations tax is so small relative total travel expenditures.

The burden of the tax will be borne mainly by middle to upper income groups, somewhat offsetting the regressivity of the property tax. The tax will also enable areas whose economic base is service oriented (tourism/commerce) to capture some of the revenues foregone by having an economic base assessed at 6 percent rather than the substantially higher assessment rate levied on industrial property. This may well be the most important feature of the tax in South Carolina. A substantial proportion of the tax-about two-thirds-will be borne by non-residents of the state.

The tax will cost very little to collect because the collection and disbursement machinery of the sales tax can easily be adapted to include an accommodations tax. While its revenue yield is not significant compared to the far more broadly based income, sales and property taxes, it can raise significant revenue in limited areas which are hard pressed and can do so quickly, equitably, and at a relatively modest cost of collection. 


\section{FOOTNOTES}

1. Direct estimates for the income elasticity of the property tax base are hard to make, since the data are not reported regularly and do not always separate out changes in the assessment rate or rates. Estimates of the state-by-state elasticities range from .47 to 1.08 , with lowest elasticities in highly agricultural states such as South Carolina. (McLoone, Eugene, "The Facts of Tax Elasticity and the Financial Support of Education," Ph.D. dissertation, University of Illinois, 1961, cited in Hirsch, Werner, The Economics of State and Local Government, McGraw-Hill, 1970, p.99) Property tax revel.ues (including increases in the mil rate) consistently lag behind total state and local tax revenues in growth rates for the 1962-72 period.

2. Financing County and Municipal Governments in South Carolina in the 1970s: Final Report, Study Committee on Alternative Sources of Revenue for Counties and Municipalities, South Carolina General Assembly, Columbia, SC, March 1980.

3. Musgrave, Richard and Musgrave, Peggy, Public Finance in Theory and Practice. McGraw-Hill, 1973, p 124-126.
4. The criteria of equity and neutrality receive major attention in Richard Musgrave's classic work, The Theory of Public Finance (McGrawHill, 1959). Benefit spillovers (non-resident contribution) is also emphasized in Musgrave and Musgrave (op. cit.). James Maxwell discusses the income, elasticity, equity, administrative costs, adequacy and neutrality in Financing State and Local Governments (revised edition: Brookings Institution, 1969, p. 126-145). The criteria of cyclical stability and distribution of revenue emerged as important supplementary criteria during the course of this project.

5. Based on a proposed 2 percent tax, 60 percent occupancy rate, and $\$ 24.40$ per room per night in 1976. These latter two were the national averages for the preceeding year. Kiawah and Hilton Head were based on $\$ 40 /$ night, which is conservative, since these are both luxury resort areas.

6. Based on data from County Business Patterns, 1970-78. For years for which annual payroll data for accommodations are not available, March data (seasonally adjusted) was used. 